\title{
Civilisations
}

Revue internationale d'anthropologie et de sciences

humaines

$62 \mid 2013$

Identité, culture et intimité

\section{Intimate stereotypes}

The Vicissitudes of Being Caliente in Touristic Cuba

\section{Valerio Simoni}

\section{(2) OpenEdition \\ 1 Journals}

\section{Electronic version}

URL: http://journals.openedition.org/civilisations/3320

DOI: 10.4000/civilisations.3320

ISSN: 2032-0442

\section{Publisher}

Institut de sociologie de l'Université Libre de Bruxelles

\section{Printed version}

Date of publication: 31 December 2013

Number of pages: 181-198

ISBN: 2-87263-042-2

ISSN: 0009-8140

\section{Electronic reference}

Valerio Simoni, «Intimate stereotypes », Civilisations [Online], 62 | 2013, Online since 31 December 2016, connection on 01 May 2019. URL : http://journals.openedition.org/civilisations/3320 ; DOI : 10.4000/civilisations.3320 


\title{
Intimate stereotypes \\ The Vicissitudes of Being Caliente in Touristic Cuba ${ }^{1}$
}

\author{
Valerio SIMONI
}

\begin{abstract}
Stereotypes about the caliente ('hot') character of Cuban people, whose origins can be traced back to the colonial past of the island, circulate widely in contemporary touristic Cuba. Drawing on nine months of participant observation of intimate encounters between foreign tourist and Cuban people, the article focuses on the practical uses of these stereotypes in everyday touristic interactions on the island. On the one hand, it appears that the caliente stereotype can help bring Cubans and tourists together, facilitating sexual encounters between them. On the other, such stereotype also hampers Cuban people's aspirations to establish stronger relational bonds with their tourist partners. Examining this tension, the article follows the vicissitudes of the caliente Cuban and teases out its alternative interpretations as national trait, tactical instrument, or expression of love. What emerges is that in responding to different demands and aspirations, the protagonists of touristic encounters work over notions of intimacy, redrawing lines of belonging and exclusion. Building on current anthropological debates in the fields of tourism, love, morality, and the politics of culture, the article provides an approach to stereotypes in everyday life that helps us rethink anthropological conceptions of (cultural) intimacy, and sheds new light on its contemporary transformations.
\end{abstract}

Keywords: stereotype, intimacy, morality, culture, tourism, Cuba.

Résumé : Dans la Cuba touristique contemporaine les stéréotypes à propos du caractère caliente (" chaud») du peuple cubain, dont l'origine remonte au passé colonial de l'île, circulent amplement. A partir de données recueillies au cours de neuf mois de travail ethnographique centré sur les rencontres intimes entre touristes étrangers et habitants de l'île, l'article met en lumière les usages pratiques de ces stéréotypes dans les interactions touristiques. D’une part, le stéréotype du Cubain caliente peut encourager ces interactions, facilitant notamment des rencontres d'ordre sexuel ; mais d'autre part, il entrave également les aspirations des cubains à établir des liens plus durables avec leurs partenaires en villégiature. En examinant cette tension, l'article aborde les vicissitudes du "Cubain caliente » et permet de dégager des interprétations divergentes qui font de lui, tantôt un trait national, tantôt un instrument tactique, et parfois une expression d'amour. En répondant à des demandes et des aspirations divergentes, les protagonistes de ces rencontres touristiques reformulent leurs notions d'intimité et redessinent des lignes d'appartenance et d'exclusion. En s'appuyant sur les débats anthropologiques en cours relatifs au tourisme, à l'amour, à la moralité, et aux usages politiques de la culture, l'article propose une approche des stéréotypes dans la vie quotidienne qui permet de repenser les conceptions anthropologiques de l'intimité (culturelle) et en éclaire ses transformations contemporaines.

Mots-clés : stéréotype, intimité, moralité, culture, tourisme, Cuba.

1 This research was supported by the Fundação para a Ciência e Tecnologia (Post-Doctoral Grant program, $\mathrm{SFRH} / \mathrm{BPD} / 66483 / 2009)$. I wish to thank the editors of this Special Issue and two anonymous reviewers for their helpful comments and suggestions. This article would not have been possible without the collaboration of the several foreign tourists and Cuban people I encountered during fieldwork in Cuba, and my deepest gratitude goes to them. 
$\mathrm{G}$ oing through the field notes from my last stay in Cuba (December and January 2010/11), and thinking about the stereotype of the caliente ("hot") Cuban, I am drawn to a small scrap of paper on which my Cuban friend Umberto ${ }^{2}$ wrote a list of "typically Cuban" expressions to Ursula, a young German woman we met in a bar of Old Havana. I had provided pen and paper, and was in charge of the English translation. Umberto's stated purpose was to teach Ursula the key words one had to know in Cuba. Tellingly, first on his list came chingar. ${ }^{3}$ Translated as "to fuck", the word was much in tune with the sexual innuendos that throughout the evening had punctuated Umberto's interaction with Ursula. Showing her complicity in the game, when it came to Ursula's turn to teach him some English, she wrote "cunt" - "the C word", as she put it. Since earlier on, Umberto - an Afro-Cuban man in his thirties - had been provoking Ursula with explicitly sexual jokes. The atmosphere of playful eroticism had reached its paroxysm when he cut out a small human figure on a paper towel - ialgo positivo! ("something positive!") he announced ${ }^{4}$ - which, on pulling its legs, would reveal an outsized penis. To the pretended embarrassment of Ursula, Umberto had then bragged about the size of his own member. Ursula, in her mid-twenties, seemed to enjoy his jokes and easygoing manners, and was not shy when it came to sexual matters. She had made this clear when telling us about the teenage Finnish girls she had had to "take care of" a few days earlier, shocked as they were by the openly sexual advances of Cuban men. Ursula acknowledged that in Cuba "things were different" as far as sex was concerned, and she seemed willing to appreciate and adapt to this different state of affairs.

While she enjoyed joking about sex with Umberto, their relationship that night stopped short of moving to the deeper level of engagement that my friend was hoping for. Concerned about Ursula's reluctance to get more intimate, at some point Umberto had called on me for help: "Say something... I cannot continue like this [playing with sexually tainted jokes] all night". He was aware that while joking contributed to create a nice atmosphere of complicity, to "ablandar los frijoles" ("soften the beans", meaning making people feel at ease) as he put it, more was required if he wished to seduce and conquer Ursula, which was ultimately his aim. Indeed, while Umberto did not necessarily mind casual sex and one-off relationships with tourist women (and he had had a lot of these in the last years), he was now more inclined to look for "serious people" (una persona seria), someone who would take seriously the possibility of having a long term, love relationship with him.

One may argue that his sex related jokes with Ursula were not the best premise to start a serious relationship, and indeed Umberto had possibly been off target in his approach that evening. However, this is not the point I want to make here. The reason I chose this little vignette to start this article on intimate stereotypes, is because it illustrates quite well the paradoxical situation several of my Cuban research participants found themselves in while interacting with tourists: a facility to rely on sexual stereotypes

2 All personal names of research participants appearing in the article are fictional.

3 More commonly spelled singar in Cuba.

4 All the direct quotes from informants appearing in the article have been translated into English and are based on the recollection of them as field notes after the events took place. 
and jokes on the one hand, and a desire for "something more" that a simple joking relationship on the other. More particularly, we are confronted here with a tension between the widespread tourism trope of the caliente Cuban and its potential to draw Cubans and tourists together in a carefree, playful mode of interaction, and Cuban people's desires and aspirations to establish stronger relational bonds with their tourist partners. It is this tension, and its generative potential to redefine intimacy and redraw lines of belonging and exclusion, that I wish to examine more closely in this article. This, in turn, will result in an approach to "stereotypes in everyday life" that may help us rethink what counts as "cultural intimacy" (Herzfeld 2005) in anthropological research. The vicissitudes of being caliente in touristic Cuba provide the ethnographic foundation for the arguments presented, which build on recent anthropological debates in the fields of tourism, the politics of culture, love, intimacy, and morality.

Empirically, I draw on a variety of ethnographic data and secondary sources related to contemporary developments of tourism in Cuba. Secondary sources are provided mainly by social sciences' literature on the intersections between tourism and sex in this Caribbean country, which addresses historical continuities in the caliente Cuban stereotype from the times of slavery and colonization $\left(16^{\text {th }}-20^{\text {th }}\right.$ century), to present day, socialist post-soviet Cuba. ${ }^{5}$ The ethnographic material comes from nine months of fieldwork carried out in Cuba between 2005 and 2011 for my doctoral and postdoctoral research projects. Initial foci of my research were the "informal encounters" taking place between foreign tourists and members of the local population in Cuba (Simoni 2009). These are encounters that developed beyond the control of the Cuban authorities and involved people who were not formally employed in the tourism industry, and which took place in the city of Havana, the rural town of Viñales (located $200 \mathrm{~km}$ west of the capital), and the beach resort of Santa Maria (in Playas del Este, a thirty minutes' drive east of Havana). In these tourism settings, I observed and participated in interactions between tourists and Cubans, ${ }^{6}$ and discussed with them the encounters and relationships they developed with each other.

In spite of its diversity, the empirical material on which I base my reflections does not provide a comprehensive picture of the touristic encounters that took place in Cuba, and is markedly biased towards the practices and discourses of heterosexual men. This, however, should not detract from the wider arguments of the article, which tend to operate on a different line of interpretation. Indeed, more that presenting the views of

5 Post-soviet refers here to the 1990s onwards. With the collapse of the Soviet Union - Cuba's privileged economic partner and ally since the $1960 \mathrm{~s}$ - the country plunged into a dramatic crisis that resulted in a period of austerity and reforms known as the "Special Period in Time of Peace" (Periodo Especial en Tiempo de Paz). This period saw the booming of international tourism - seen as a crucial way to draw much needed hard currency into the country - go hand in hand with the escalation of informal tourismoriented economic activities.

6 My use of the categories of "tourists" and "Cubans" in this article does not imply to the existence of two homogenous groups of actors with clearly defined characteristics. Instead, "tourists" and "Cubans" are apprehended as emic, emergent and relational categories, as a "grammar of distinction" (Comaroff \& Comaroff 1997: 25) that was particularly salient in the context of international tourism in Cuba (Simoni \& McCabe 2008; Simoni 2009). The situations in which the stereotypes and forms of (cultural) intimacy that I discuss in this article were enacted, were key grounds for the articulation of this grammar of distinction. However, they were also fraught with possibilities to challenge it, creating occasions to negotiate and redraw lines of belonging and exclusion. 
different "types" of tourists and Cuban people, the reasoning here aims to highlight heterogeneity within the lives of the subjects of my investigation - the multiple and paradoxical positionings and subjectivities they inhabited as they responded to different moral demands and pragmatic concerns. The eclectism of sources and points of view thus becomes a device to unsettle reified conceptions of what (cultural) intimacy is about and - crucially - what it can become.

\section{The caliente Cuban as national trait: From the colony to contemporary tourism}

Several scholars writing about the recent developments of tourism in Cuba underline continuities between the sexualized images of "hot" Cuban people and the slavery and colonial past of the island (Coco Fusco 1997; Kneese 2005; Kummels 2005; Sánchez Taylor 2000). Within this analytical framework reference is often made to the persistent image of the "mulatta woman" (la mulata) as the "daughter of love" and illicit lover of white men (Coco Fusco 1997: 57). Such image, which dates back to the times of slavery, can accordingly be found again in postcolonial Cuba, where la mulata has become a national symbol. ${ }^{7}$ These considerations converge with the wider remarks of Kempadoo (2004), O’Connell Davidson \& Sánchez Taylor (1999), and Sánchez Taylor (2000) on the links between racist and colonial constructions of black women as "naturally hot" and promiscuous and the developments of "sex tourism" in the Caribbean. For these authors, the reproduction of racial stereotypes explains the attraction of the Caribbean as a tourist destination where sex is deemed easy and even a natural ingredient of the holiday experience. Besides the eroticization of mulatas and black women, "white stereotypes of primitive black male potency" (de Albuquerque 1998: 50), and colonial, sexualized racist fantasies of "the 'big black dick"” (Sánchez Taylor 2000: 49), are also said to lure female (sex) tourists to Caribbean countries like Jamaica, Barbados, Cuba, and the Dominican Republic (de Albuquerque 1998; Kempadoo 2004; Sánchez Taylor 2000).

What my ethnographic material suggests, is that besides continuities in the racialization of sexuality - most notably in the (hyper)sexualization of Afro-Cubans (see Allen 2007 \& Fernandez 1999; 2010) - the stereotype of the caliente Cuban could also be re-actualized in a more culturalist/nationalist vein in specific tourism contexts, and applied to Cubans with little regard to their racial attribution. In her study of interracial couples in contemporary Cuba, Fernandez also notes that "perceptions of Cubanness, in general, were closely linked with sexuality, and there was a sort of national pride about

7 See in particular the works of Coco Fusco (1997), Kneese (2005), Kummels (2005) \& Lundgren (2011). A parallel may also be drawn here between discourses surrounding the mulata in Cuba and those on the chabine in the French Antilles (Mulot 2008). 
Cuban's mythical sexuality and ardency" whereby "Cuban men and women were seen to possess an uncontrollable "latino passion", particularly in comparison to Europeans and North Americans" (Forrest 1999 quoted in Fernandez 2010: 126) It is precisely such comparison and relational opposition that acquired salience in the tourism contexts where I worked, and that helps explain the overarching characterization of Cuban people as "hot", or at least "hotter" than the foreigners visiting the tropical island. ${ }^{9}$ Since the mid-1990s, tourism promotion material emphasized the "exuberant", "passionate" and "sensual" character of Cuban people (Michel 1998), which is still a recurrent way of describing the island's inhabitants in tourism guides and publications. Accordingly, Cuba becomes "probably the most sensual country on hearth, not to say sexual" (Gloaguen ed. 2007: 36), a place where "[b]odies are a free source of fun; sexual activity starts young and goes on to a full and interesting (often promiscuous) adult sex life" (Time Out 2004: 27). From "warmth" and "exuberance" to "passion" and "sensuality", different allegedly "Cuban" traits are harmonized and made to converge, leading this literature to articulate sexual portrayals of the caliente Cuban.

During fieldwork, I was repeatedly confronted with Cuban people banking on the image the country had acquired on the global tourism market and praising their amazing sexual skills to foreign visitors. "What? You've never tried [sex with] a Cuban? You don't know what you're missing my friend..." could be the provocative remark, often tainted with humour and accompanied by a smile or a wink charged of innuendo. "Once you make love with a Cuban, you don't backtrack!" was another classic. These playful comments could be addressed light heartedly, and serve as a way to break the ice and bring about an informal atmosphere of complicity and intimacy with tourists. They generally offended no one, but evoked instead the notion that by sharing jokes and stereotypes tourists and Cuban people were also partaking of a common discourse (Rapport \& Overing 2000: 347), one marked by humour and amusement (Simoni 2008a). Far from being always innocent, however, such comments could also serve to test the tourists' interest in sexual relationships with Cuban people, foreshadowing intimate relationships between the protagonists involved. Tourists could subsequently be encouraged to "let go" and indulge in the exceptional sensuality and sexuality of the Cuban Other. If they had really come to Cuba to discover another country and another culture - as normative tourism discourses prescribed - then they had to experience first-hand one of its quintessential typicalities, the caliente Cuban at stake could argue (Simoni 2011). Gaining intimate knowledge of the destination was here taking a very concrete connotation.

8 Discussing the importance of "eroticism in the conception of 'Cubanness"” (2011: 27), Lundgren links "the racialization of 'Cubanness', symbolized by the eroticized figure of the mulata", to the "inclusion of eroticism as a positive ingredient in a national particularity" (90), exemplified for instance in the Revolutionary Government's program on sexual education (33), a program that, however, also took care of opposing "the values that should accompany 'socialist sexuality', such as love, cooperation, mutual respect, equality" (84), to "uncontrolled sexual expressions" and the "risks and dangers of "promiscuity" (85).

9 An interesting parallel may be drawn here with Piscitelli's work on sex travel in Fortaleza (in Brazil's North-eastern coast), and her reflections on "the production of the idea of a 'Brazilian sexual culture" (2006: 4). 
These lines of reasoning were also common currency among the single tourist men I encountered, who were quite keen to employ a reductive paradigm of "intercultural exchange" to justify their potentially controversial relations with Cuban women (Simoni 2011). Thus, recounting me about his sexual experiences in Cuba, Giovanni, an Italian man in his thirties, emphasized for instance how Cuban women simply liked sex. According to him, who had been travelling regularly to Cuba for several years, foreigners should not worry about engaging intimately with the local population. Instead, one should indulge and appreciate first hand their amazing sexuality. In the course of my fieldwork, I became particularly well acquainted with the large population of single Italian tourist men, like Giovanni, which had become a permanent feature in Playas del Este since the 1990s. Among them, the association between Cuba and sex was rather straightforward, echoing the reputation this country had acquired in Italy as a crucial node in "sea, sun, sand and sex" tourism destinations, alongside other countries such as Thailand and Brazil. ${ }^{10}$

The reputation of Cuba as a tropical land ripe with sexual opportunities has led to controversies over the responsibilities of the Cuban government in promoting such an image. Thus, some scholars consider that in its effort to attract foreign visitors to their country and promote Cuba abroad, the attitude of the Cuban government has been ambiguous at best, as it tried to appeal to a an ample range of tourisms, including "sex tourism" (Clancy 2002). Here, we may argue, is where the mulata myth backfired on the Cuban authorities' efforts to promote tourism. Following Herzfeld's remarks on the potential vicissitudes of stereotypes and the "highly labile" "content of cultural intimacy" (2005: 57), we could argue that what may have been a source of pride for Cuba - the beauty and hotness of its mulatas - gradually became a source of embarrassment once this image was increasingly associated with sex tourism and prostitution. Making a noticeable entrance in the international tourism trade in the $1990 \mathrm{~s}$ - the numbers of international tourists skyrocketed from 275'000 in 1989 to more than 1 million in 1997 (Quintana et al. 2005: 113) - Cuba also entered the regimes of value and moral critique that were associated with it. This is also when the focus of attention shifts from the question of essentializing the caliente Cuban stereotype, to its strategic deployments and manipulations.

\section{The manipulative caliente: Unpacking discourses of instrumentalization}

With the booming of international tourism in the 1990s, the growing reputation of Cuba as a pleasure destination and "sex tourism" paradise captured the attention of international media and scholars. The debate surrounding "the explosion of sex tourism" in the 1990s brought back daunting images of pre-revolutionary Cuba, and particularly

10 While the tourists featured in this article are mostly single heterosexual Italian men, and the Cubasex association seems particularly salient in Italy in comparison to other tourist-sending countries, the stereotype of the caliente Cuban was widely diffuse among tourist men and women of different nationalities. Albeit out of the scope of this article, an increased attention to the provenance, gender and class of tourists, for instance, and to various modalities and expectations of travelling to Cuba, may help tease out differences and nuances in the articulation of the stereotype, and the way it informed (or not) a variety of tourist-Cuban interactions. 
the 1950s, when this "pleasure island" (Schwartz 1999) was perceived as the "tropical playground" of the US and known in some circles as the "brothel of the Caribbean". The establishment of continuities or ruptures between pre-revolutionary and contemporary Cuba progressively became a fertile ground for political instrumentalizations, and is still today an issue of contention between supporters and detractors of the Cuban political system (Cabezas 2009; Kummels 2005; Valle 2006).

Berg (2004) has underlined how the official position of Cuban institutions tends to emphasize differences between a "classic" definition of prostitution as caused by poverty (exemplified by prostitution in pre-revolutionary $\mathrm{Cuba}$ ), and the new forms of prostitution of the 1990s, seen as a result of moral decadence and people's "desire for the satisfaction of "luxurious tastes"' (Berg 2004: 51). From the Spanish jinete (jockey, rider), the neologism jineterismo evokes in touristic Cuba the riding of foreigners for instrumental purposes, and is often associated with notions of tourism hustling and prostitution, albeit its meanings and attributions remain highly flexible and contested and tend to operate along discriminatory lines of race, class, gender, and nation (Berg 2004; Cabezas 2009; Fernandez 1999; Simoni 2008b, 2009). For Palmié, in much popular discourse jineterismo "speaks to morally highly ambiguous notions about commoditized exchange, luxury consumption, and the creation of social identities through processes of objectification" (2004: 243). The "victims" of such objectification become the tourists, here cast as preys of the unscrupulous jineteros and jineteras who "ride" them for purely instrumental motives, extracting cash and other desired commodities from them (imported goods, entertainment, etc.).

As already suggested by the examples considered above, informal interactions between tourists and Cubans could rely on what anthropologists have conceptualized as instrumental uses of culture and practical and strategic essentialism (see Fox \& King 2002, Herzfeld 2005). In this respect, what narratives of jineterismo foreground is that Cubans' strategic essentialisms - the caliente stereotype being one of them - were geared at luring tourists into sexual/romantic relationships with the aim of gaining money or migrating aboard via marriages and tourist sponsored invitations. These were indeed the sort of narratives that several of my Cuban informants activated when talking among peers about their relationships with foreign tourists. In these contexts of interaction, they tended to objectify tourists, referring for instance to them as piezas ("pieces"), and avoided delving on the emotions they felt for their foreign partners something that could have made them look foolishly vulnerable and naïve. Instead, they would align themselves to the semantic registers and moral discourse of jineterismo, becoming "tourist-riders" who had conquered their foreign "victims" for essentially instrumental purposes, to provide for their socio-economic needs and desires and those of their family. Crucially, these were the kind of discourses that their tourist partners were not supposed to hear, and which may therefore be viewed as part of a realm of cultural intimacy (Herzfeld 2005). The problem, however, was that these very same instances of strategic essentialism were also being made public and circulated worldwide via tourism guidebooks and other international media, and had therefore 
been already colonized by tourism. ${ }^{11}$ Indeed, by the time of my fieldwork, jineterismo had become integral to what Cuba was about and tourists had to expect.

What is important to consider here is tourism's drive to reach into the most intimate realms of the places and lives that come onto its path, so much so that MacCannell (1973; 1976), one of the first theorists of modern tourism, made of such quest for the "authentic" Other and "intimacy of relations" the key tenet of his theorization. Despising the idea of being deceived with "fake" appearances, many tourists I met were constantly puzzled about the "real" intentions and motivations of the Cubans interacting with them. Here is where narratives of jineterismo could serve as a useful "competence building proposition" (Latour 2005: 211), and provide key interpretative resources to "unmask" the "secret" motivations of Cuban people. What seems particularly striking of tourism in relation to the model of cultural intimacy articulated by Herzfeld (2005) is such appetite for unlocking, bringing to light, and publicizing those spaces of cultural intimacy that members of the visited population may be trying to keep secret and preserve for themselves. Calling for a more historical appreciation of the model and its" echoes of a "residual binarism" that posited "a private cultural space shielded from the critical view of the powerful" (2005: 46), Herzfeld urges us to "see how and where binarism actually crept into our collective discourse" (Ibid.). Contemporary international tourism, I argue, may be precisely a key process actualizing notions of "private cultural space" on the one hand, and feeding tourists with narratives of what these spaces are about on the other. So where does this leave the stereotype of the caliente Cuban and its strategic uses? Are Cubans' strategic uses of it the locus where cultural intimacy may be found? To start addressing these questions from a reverse angle, let me consider some examples that show how the stereotype of the caliente Cuban could become a double edged sword for Cuban people.

Consider the advice given by Armando - an Italian man in his sixties and regular visitor to Cuba for more than two decades - to an Italian teenager who had just arrived in Cuba for the first time and was eager to engage with Cuban women:

Don't go to the disco, they are all hookers there, always the same ones... Better to just hang around the surroundings of the Habana Libre [a huge Hotel in the most lively area of Vedado, in Havana], the Coppelia [a very famous ice-cream shop near the Habana Libre] where people are queuing [...] When you find someone you fancy, just tell her "que linda" (how beautiful you are) [...] You just invite her to a restaurant, you pay for food. Then [Armando puts on a cunning smile] you tell her that you are in love, that you want to marry her, that you want to bring her to Italy... and then you'll see you won't need to pay a thing [for having sex with her].

While advising the teenager to play out a "proper" seduction process, performing appropriate gendered roles for courtship, the seduction enterprise that Armando prescribed simultaneously relied on the tourist card of a promise of a better life, and the tactical possibility of playing with false hopes of "love, marriage, and migration" to lure Cuban women into having sex for no payment at all. Armando's scheming and

11 For one, any major contemporary guidebook on Cuba is likely to have at least a small section devoted to the phenomenon of jineterismo, as it is the case in the popular Guide du Routard (Gloaguen (ed.) 2007), Lonely Planet (Gorry 2004), Time out (2004) or Rough Guide (McAuslan \& Norman 2003). 
tactical play relied on the assumption that this - to migrate - what indeed what every Cuban wanted, no matter how they tried to disguise it. In his circle of Italian friends all expert long-term tourists - love was at best a tool to be cynically deployed to deceive Cuban women to sleep with them "for free".

When discussing with Alvaro and Sandro about the possibility of marrying a Cuban and move back to Italy with her, these two Italian men in their sixties also made it clear that this was the worst error one could make. For them, to have a Cuban partner in Italy was "like keeping a bird in a cage" (E come tenere un uccello in gabbia) - an expression that hinted at the inexhaustible sexual appetite of Cubans, a "hotness" that sooner or later would lead them to abandon you for another man. In tune with this line of reasoning was the proverb "Moglie e buoi dei paesi tuoi!" ("Wife and ox [should be] from your own country/backyard!"), which came out in the same conversation and which implied that while it was ok to enjoy sex with "hot" Cuban women, as far as serious decisions like marriage were concerned it was wiser to choose someone with your own background, from your own country, someone you could trust. ${ }^{12}$ While the views of these experienced tourists were rather extreme and may be located at one end of tourists' assessments of intimate relationships with Cuban people, my ethnography suggests that most tourists, women and men confounded, were highly sceptical about the suitability of getting entangled in any long term relationship with Cubans. The spectre of possible deception, contrived emotions, interested marriage, and other instrumental machinations at their expenses was often lurking at the back of their minds.

These lines of reasoning were reifying a divide between Cuban's self-presentations to outsiders and their actual motivations and agendas, which were deemed ineluctably strategic. Such an approach, I would argue, may be particularly tempting for scholars of tourism, particularly when combined with a focus on structural inequalities and an emphasis of local resistances to global forces. The risk, in this case, lays in "romanticizing resistance" (Abu-Lughod 1990), and with it the image of the cunning locals that in spite of their subaltern position are able to trick and deceive the structurally advantaged tourists, for which academics have traditionally displayed little sympathy (see Crick 1995). The self-evident character of this interpretation may be further reinforced and its moral underpinnings therefore less likely to be reflexively acknowledged - in a Caribbean context where cunning responses to colonial domination have captured much anthropological attention, and have even been considered "to embody the most authentic in Caribbean culture" (Wilson 1964, cited in Freeman 2007: 5). In Cuba, the socialist government itself rests on a long tradition of nationalist rhetoric of resistance to colonial and imperialist powers. In the generalized climate of crisis of post-soviet Cuba, the notion of la lucha ("the struggle") - one of the key terms of revolutionary symbolism - progressively turned into a common expression to indicate Cubans' day-to-day struggle to get by, to look for dollars "in the street" (en la calle) (Berg 2004; Bisogno 2010; Palmié 2004). While people engaging informally with tourists

12 The parallel is striking here with Coco Fusco's considerations on the mulata's longstanding association with illicit sex, and with the adagio that circulated in Caribbean plantations: white women to marry with, black women for work, and mulatas to make love (1997: 57). In this case, Cuban women as a whole were taking on the role ascribed to mulatas in the colonial proverb, pointing again to the increasingly culturalist/nationalist translation of traits originally associated with specific racial attributes that tourism seems to foster (see Piscitelli 2006). 
were able to inscribe their actions within this moral framework, the Cuban authorities' condemnations of jineterismo as an immoral endeavour motivated by a lust for capitalist consumption, excluded their engagements from the legitimate realms of la lucha.

It is in this research context, where judgments about what counts as legitimate resistance are themselves a politically and ethically fraught object of struggle, that I believe researchers must become acutely sensitive and reflexive of their own moral assumptions and desires (Fassin 2008, Zigon 2010), and pay attention to the competing moral claims they encounter during fieldwork. Not to do so may reduce the interpretative possibilities explored, obscuring practices that seem to counter even our most cherished views of tactical resistance and strategic essentialism. To make my point clear, this is not to say that such tactics should not be recognised when they are self-professed by our research participants - as when Cuban people boasted about their cunning deception of tourists. Rather, the approach I am advocating encourages us to remain open to other possibilities and alternative endings, so as to recognise, and take seriously, also those situations in which ascriptions of tactical and instrumental behaviours are explicitly refuted and are perceived as hampering the range of subjectivities to which our informants aspire.

The image of the cunning jinetero/a deceiving tourists via duplicity and dissimulation is becoming in Cuba a reified construct from which my research participants - themselves key actors of its propagation - found it hard to extricate. As I show in the following section, there were indeed instances in which the "hypothesis" of "duplicity and dissimulation" as the quintessential "arms" "of the dominated" (Callon and Rabeharisoa 2004: 20) became a conceptual prism (and prison) extremely hard to refute and disentangle. Such an image was mobilized by the government (replacing perhaps "dominated" with "luxury seeking marginals") to condemn jineterismo and justify its repression, ${ }^{13}$ was featured in tourism guidebooks and other international media on tourism in Cuba, was activated by my Cuban research informants when bragging about their jinetero-like exploits at the tourists' expenses, and - as shown by the above examples - it was also evoked by tourists to justify their cynical counteracting manoeuvres against jineterismo, and erect insurmountable boundaries between "us" and "them". As I now explore, this reified divide between tourists and Cubans, which reiterated the stereotype of the caliente Cuban while delimiting its suitable range of action - i.e. (instrumental) sex - was one that Cuban people who engaged sexually with foreigners could be adamant to overcome. On such occasions, their enactments of the caliente Cuban wished to bring about other relational possibilities and aspirations.

13 From 1996 onwards, the Cuban government operated several crackdowns and waves of repression on jineterismo, relying on a provision of its Penal Code that dealt with the "state of dangerousness" (el estado peligroso, also known as indice de peligrosidad): "the special proclivity of a person to commit crimes, demonstrated by a conduct that is in manifested contradiction with the norms of socialist morality" (Asamblea Nacional del Poder Popular, n.d.). After three "warnings" (cartas de advertencia), Cubans accused of asedio del turista (siege/hustling of tourist) risked facing one to four years in a rehabilitation centre. 


\section{The loving caliente: reclaiming relational possibilities and aspirations}

A first case I would like to discuss here is a story from my friend Manuel. In his late twenties, Manuel had been in a relationship with Marina for a couple of years. During that time Marina, a young Spanish girl of about the same age and widely recognized by Manuel and his close friends as a "beauty" from a "good" (wealthy) family, had come to visit him repeatedly in Cuba, bringing her parents with on one occasion. When talking about their relationship, Manuel was keen to boast his sexual exploits. For instance, he liked to brag about how he "broke her in two" when they first made love, so much so that after this initiation to "Cuban sex" Marina was allegedly unable to sit down for two days. Manifestly, she had encountered the quintessential caliente Cuban, one who could show her what "real sex" - "Cuban style" - was all about: "No one fucks like Cubans!" had boasted Manuel on another occasion. Besides all these narratives of sexual prowess, Manuel also insisted on the seriousness of his commitment to her, his novia ("girlfriend"). Their relationship was indeed for him a very promising one, and raised hopes of a possible marriage and future in Spain together. These, however, were delicate issues to talk about, and Manuel had carefully avoided bringing them up in his conversations with Marina, since he did not want to give her the impression that this was what he was after. Significantly, in one his many tales about his relationship with her and how it all ended, Manuel told me that it was precisely when Marina started insinuating that he wanted marry her in order to migrate from Cuba, that he had decided he could no longer stay with her.

Whether this was truly the reason that prompted their separation is beside the point here. According to Manuel's narrative, it was, and this, I argue, gives us a good vantage point into his aspirations and moral way of being Marina's boyfriend. Her accusations implied the existence of instrumental agendas behind Manuel's professions of love. They brought to life the image of the cunning and deceptive jinetero, denying him the possibility of being "simply" in love, to be capable of sentiments that had nothing to do with the structural inequalities that separated them. ${ }^{14}$ This, for Manuel, was a move fraught with important implications, and one you could not undertake lightly. Marina had shown that she did not trust him, and that "she had no heart" (no tiene corazón). Similar conclusions were reached by other Cuban research participants I interacted with. Take for instance Emilio, who had been promised marriage by his Austrian lover and had travelled there only to find himself "used for sex" during two months, and with no wedding prospect in sight. "I am not a sex machine!" was his outraged reaction, as he complained about tourists' misrecognition of his ability to love and need for love. On other occasions, Emilio was led to question the alleged uniqueness of Cuban's

14 To clarify my approach here, I should highlight that I do not wish to idealize "love", nor see it as "morally superior" to "sex", but simply to account for my informants views on the subject. As recent anthropological work has shown, love and intimacy come with their own disciplining effects, and it is precisely in love - according to Elizabeth Povinelli - that one may "locate the hegemonic home of liberal logics and aspirations" (2006: 17). 
sexuality. While de-essentializing de caliente stereotype, he also recognized that tourist women could vary a great deal in terms of "hotness" and sexual exuberance. ${ }^{15}$

Going back to the context of Santa Maria and the single tourist men that patronized that beach, sentences like "You must be crazy to fall in love with a Cuban!" were common place. This was a realm where the caliente Cuban was to be kept "sex bound", without letting inappropriate sentiments and affections overflow. It was in this environment adverse to any sort of romanticism that I became familiar with the love story of Bruno and Yunila. Bruno had been travelling with a group of Italian friends to Cuba. For him, and unlike some of his more experienced travel companions, it was the first time on the island, and when they had arrived in the town of Las Tunas (several hours east from Havana), he had fallen in love with Yunila, a Cuban girl in her twenties and about ten years younger than him. By inviting her back to Havana so that they could spend the rest of his holiday together, and by openly expressing the love he felt for her, Bruno had become a laughing stock and victim of scornful insinuations from his companions. Spending several days in their company, I was saddened by the teasing remarks made by Bruno's fellows, who constantly joked about him being in love, and occasionally referred to Yunila as "a bitch", a jinetera like all the others who had managed to deceive him, feigning love to get hold of his money, marry him, and eventually migrate to Italy. Repeatedly scolded as naïve and blind to evidence, Bruno was embarrassed and hurt by his friend's remarks. Yunila on her side, was even more saddened by their accusations, and repeatedly complained about being treated as a prostitute. They were denying her any fidelity to the love she was professing for Bruno.

What these different cases and many other pointing in the same direction led me to recognise, was that to imply an inevitable horizon of self-interestedness in Cubans' professions of love, and to force this interpretation on them, was to negate them an important venue to fulfil their desires and aspirations. By insisting on their commitment to a disinterested, affection based love, Cuban people were trying to align their moral selves to those of their tourist partners, and thus lay claim to the possibility of belonging together in a shared social world, one that was not dominated by material concerns and structural inequalities. The aspiration at stake here was to be recognized capable of a "love" they assumed would hold sway under "normal conditions of existence"as opposed to the context of exceptionalism, enduring crisis, scarcity, and isolation

15 During fieldwork, I came across other instances in which the stereotype of the caliente Cuban became the subject of explicit controversies and contestations. In the light of disappointing sexual experiences with Cuban partners, some of my tourist informants were thus led to question any supposedly "natural" and generalized "hotness" ascribed to Cubans, and to emphasize instead individual differences in sexual effervescence, proficiency, and restraint. In this sense, and as I have shown elsewhere (Simoni 2008a; 2008b), touristic encounters were fraught with possibilities to reflexively work over stereotypes. As one of the anonymous reviewers of this article pointed out, it is also in uncovering these alterations and contradictions that ethnography can add to an historical analysis of the stereotype's formation and resilience. An increased attention to the trajectories of my research informants, and the way articulations and contestations of the "hot" Cuban stereotype could be informed by their personal experiences, is another line of enquiry that remains largely out of the scope of this article. 
they associated with Cuba, and which they wished to overcome. ${ }^{16}$ In this context, their relationships with tourists could provide a key platform to claim "membership" to a "global society" (Ferguson 2006) from which they felt left behind, and to fulfil other socio-economic needs and aspirations.

Indeed, what remains very important to consider here, is what these professions of love could also enable and achieve at a more pragmatic level. With love came a range of moral responsibilities and obligations. For the Cuban person at stake, this could mean being sent a monthly allowance to face the hardships of life in the island when their foreign lover was absent, or being able to marry their partners and join them in their countries. What was extremely important for them to preserve the moral configuration on which their love was grounded, was for these obligations and responsibilities to be experienced not as love's defining motive, but rather as a sentiment-driven outcome of it, a sort of epiphenomenon. In other words, people first loved each other, in uncompromising and uncalculated ways, and subsequently, simply naturally, helped each other out as much as they could. Coming now to the conclusion of this article, where do these considerations leave us in regards to the question of intimate stereotypes and cultural intimacy?

\section{Conclusion}

I have emphasized in the last section the importance of recognising tourists' and Cuban people's aspiration to move beyond reductive readings of the caliente Cuban, and of paying attention to the emotional, moral, and pragmatic possibilities this opened up in their relationships. Professions of love, however, should not obliterate the fact that the very same people could also deceive each other. Nor shall they obscure the possibility that in other contexts of interaction (like when gossiping among peers), Cubans could still brag about jinetero/a-like feats at the expenses of their foreign partners, while tourist could boast about emotionally bound, sex-only engagements with caliente Cubans. Instead of trying to resolve the contradiction inherent in the coexistence of these incommensurable forms of engagement - which often seemed to negate each other - or aprioristically rank them as more or less real, it seems both more sensitive and analytically fruitful to engage in the sort of "ethnography of moral reason" that Sykes has recently called for, aimed at providing "specific accounts of how people negotiate paradoxes in their daily lives" (2009: 15). Indeed, I would argue that the productive and persistent ambiguity of touristic encounters in Cuba was precisely what could enable, at all times, such radical shifts between different modes of engagement and moral dispositions.

The anthropological approach advocated here is one that heeds Moore's recent calls to pay a closer attention to "the aspirational character of our relations to others" (2011: 10), and to our research participants' interest 'in creating new connections, new

16 A fruitful parallel may be drawn here with Patico's (2009) reflections on how international matchmaking provides Russian women and American men a way to seek "normalcy" in their personal lives. Pertinent lines of interpretation to illuminate the Cuban case can also be found in other recent anthropological research on love and intimacy (see Cole \& Thomas (eds) 2009; Faier 2007; Padilla et al. (eds) 2007; Povinelli 2006; Zelizer 2005). 
meanings, novel forms of relation" (9). Once we start doing this, it appears that forms of "subjectification" and "self-stylization" - like the caliente Cuban considered here "while engaged in the normative and with distributions of power, cannot completely bind people to identities, particular forms of the self or external powers" (Moore 2011: 16). By following the vicissitudes of being caliente in touristic Cuba, one of my intents was precisely to show that its' normative character and inscription in colonial history and structures of inequality does not limit the possible outcomes of its actualization in concrete moments of interaction between tourists and Cuban people.

What is more limiting, I would argue, is a reductive and reified application of the paradigm of strategic essentialism to illuminate the stereotype and its uses, a line of interpretation to which tourist guidebooks, the Cuban government, tourists, scholars, as well as my research participants, seemed often to resort. This line of interpretation becomes all the more insidious when we are dealing with relationships that develop through tourism. As the Cuban case shows, this is a context in which notions that recall Hochschild's "emotional labor" (1983), or what Herzfeld conceptualizes as "simulacra of sociality" (2005: 6), are reflexively deployed by the protagonist of touristic encounters to make sense of their relationships. These interpretative grids had become so effective and widely distributed that they seemed to work as self-fulfilling prophecies, foreclosing other relational possibilities and leading people to dismiss them as naïve illusions. By explicitly seeking out, targeting, and unpacking "typical" instances of "cultural intimacy", by providing tips, formats and standards to facilitate the tourists' appreciation of it, tourism orderings of the world and their anthropological understanding urge us to renew our conceptions of what counts as "cultural intimacy", and to rethink its possible transformations.

Discussing contemporary examples of changes in the content of "cultural intimacy", Herzfeld argues that "[w]hat persists is the circumstance that there is always something to defend" to maintain "a sense of cultural commonality." (2005: 58). What my ethnographic material suggests is that via their professions of love to foreign tourists Cuban people were simultaneously striving to redefine boundaries of belonging and commonality. They were distancing themselves from a dominant view of cultural intimacy that saw them - and their enactments of the caliente Cuban - as always strategizing, manipulating, and labouring with affects and emotion. The cultural intimacy they were delineating may instead be seen as a forward looking aspirational project, an intimacy not so much grounded on nostalgia and a common history, but oriented towards a future and a world of possibilities that lay beyond Cuba's shores. Tourism became a privileged platform where these forward looking forms of intimacy could be acted out, a realm of interaction where new moral subjectivities, affects and emotions could be experimented, (re)claimed, and tested.

The test they had to pass, however, was the arduous one of overcoming wellrehearsed, well scripted, and globally circulating interpretations of the caliente Cuban. For tourists travelling to Cuba, fascinated by the prospect of penetrating realms of local cultural intimacy, the desire could be to experience such "hotness" while leaving it intact, thus preserving its otherness, encompassing it rather than assimilating it. But their expectations and desires could run counter Cubans' aspirations for an intimacy that would enable to belong in a common social and cultural world. Tourism thrives on differences, reproducing and reifying them, and this brings us back to the tension 
Cubans could experience between being caliente - enacting a subjectivity they could themselves cherish as a form of cultural intimacy, and that also satisfied tourists' desires for Otherness - and aspiring to become also something else, something more, something at one with their tourist partners. Someone, in other words, that was intimately entangled in the foreigners' lives. This, I would argue, may be the emerging forms of cultural intimacy that ethnographies of touristic encounters can help us grasp.

\section{References}

Abu-Lughod, Lila, 1990. "The Romance of Resistance: Tracing Transformations of Power Through Beduin Women", American Ethnologist 17: 41-55.

Allen, J. S., 2007. "Means of Desire’s Production: Male Sex Labor in Cuba", Identities: Global Studies in Culture and Power 14: 183-202.

Asamblea Nacional del Poder Popular, n.d. Código Penal: Ley nr 62. Cubanet. Retrieved 6 February 2009 from http://www.cubanet.org.

Berg, M. L., 2004. "Tourism and the Revolutionary New Man: The Specter of Jineterismo in late 'Special Period' Cuba", Focaal - European Journal of Anthropology, 43: 46-56.

Bisogno, Flora, 2010. "Vivere nell'informalità: Luchar nella Cuba post-sovietica". Unpublished PhD thesis, Università degli Studi di Milano Bicocca.

Cabezas, A. L., 2009. Economies of Desire: Sex and Tourism in Cuba and the Dominican Republic. Philadelphia: Temple University Press.

Callon, Michel \& Vololona Rabeharisoa, 2004. “Gino's Lesson on Humanity: Genetics, Mutual Entanglements and the Sociologist's Role", Economy and Society 33 (1): 1-27.

Clancy, M., 2002. "The Globalization of Sex Tourism and Cuba: A Commodity Chains Approach", Studies in Comparative International Development 36 (4): 63-88.

Coco Fusco, 1997. “Jineteras en Cuba”, Encuentro de la cultura cubana 4/5: 52-64.

Cole, J. \& L. Thomas (eds), 2009. Love in Africa. Chicago \& London: Chicago University Press.

Comaroff, J. L. \& J. Comaroff, 1997. Of Revelation and Revolution Vol. 2: The Dialectics of Modernity on a South-African Frontier. Chicago \& London: University of Chicago Press.

Crick, M., 1995. “The Anthropologist as Tourist: an Identity in Question”, in M.-F. Lanfant, J. B. Allcock \& E. M. Bruner (eds), International Tourism. Identity and Change, 205-223. London: Sage.

de Albuquerque, Klaus, 1998. "In Search of the Big Bamboo", Transitions 77: 48-57.

Faier L., 2007. "Filipina Migrants in Rural Japan and their Professions of Love", American Ethnologist 34 (1): 148-62.

Fassin, Didier, 2008. "Beyond Good and Evil?: Questioning the Anthropological Discomfort with Morals", Anthropological Theory 8 (4): 333-344.

Ferguson, J., 2006. Global Shadows: Africa in the Neoliberal World Order. Durham \& London: Duke University Press.

Fernandez, N., 1999. "Back to the Future? Women, Race, and Tourism in Cuba", in K. Kempadoo (ed.), Sun, Sex, and Gold: Tourism and Sex Work in the Caribbean, 81-89. Lanham: Rowman \& Littlefield Publishers.

-, 2010. Revolutionizing Romance: Interracial Couples in Contemporary Cuba. New Brunswick, New Jersey \& London: Rutgers University Press.

Fox, R.G. \& B. J. King (eds), 2002. Anthropology Beyond Culture. Oxford \& New York: Berg. 
Freeman, Carla, 2007. "Neoliberalism and the Marriage of Reputation and Respectability: Entrepreneurship and the Barbadian Middle Class", in M. Padilla et al. (eds), Love and Globalization: Transformations of Intimacy in the Contemporary World, 3-37. Nashville, TN: Vanderbilt University Press.

Gloaguen, P. (ed.), 2007. Le Guide du Routard: Cuba. Paris: Hachette.

Gorry, C., 2004. Lonely Planet: Cuba. Footscray: Lonely Planet Publications.

Herzfeld, M., 2005. Cultural Intimacy: Social Poetics in the Nation State. London \& New York: Routledge.

Hochschild, A. R., 1983. The Managed Heart: Commercialization of Human Feeling. Berkeley: University of California Press.

Kempadoo, K., 2004. Sexing the Caribbean: Gender, Race, and Sexual Labor. New York \& London: Routledge.

Kneese, Tamara, 2005. “La Mulata: Cuba’s National Symbol”, Cuba in Transition 15: 444-452.

Kummels, I., 2005. "Love in the Time of Diaspora. Global Markets and Local Meaning in Prostitution, Marriage and Womanhood in Cuba", Iberoamericana 5 (20): 7-26.

Latour, B., 2005. Reassembling the Social: An Introduction to Actor-Network-Theory. Oxford: Oxford University Press.

Lundgren, S., 2011. "Heterosexual Havana: Ideals and Hierarchies of Gender and Sexuality in Contemporary Cuba". Unpublished PhD thesis. Uppsala University.

MacCannell, D., 1973. "Staged Authenticity: On Arrangements of Social Space in Tourist Settings", The American Journal of Sociology 79 (3): 589-603.

-, 1976. The Tourist: A New Theory of the Leisure Class. London: Macmillan.

McAuslan, Fiona \& Matthew Norman, 2003. The Rough Guide to Cuba. Rough Guides.

Michel, F., 1998. "Le tourisme international: une bouée de sauvetage pour Cuba?", in F. Michel (ed.), Tourismes, Touristes, Sociétés, 251-287. Paris: L'Harmattan.

Moore, Henrietta L., 2011. Still Life: Hopes, Desires and Satisfactions. Cambridge: Polity.

Mulot, S., 2008. "Chabines et métisses dans l'univers antillais”, CLIO. Histoire, femmes et sociétés 27, Retrieved 24 July 2012 from http://clio.revues.org/index 7447.html.

O’Connell, D. J.\& Taylor Sánchez, J.1999. "Fantasy Islands: Exploring the Demand for Sex tourism”, in K. Kemadoo (ed.), Sun, Sex, and Gold: Tourism and Sex Work in the Caribbean, 37-54. Lanham [etc.]: Rowman \& Littlefield Publishers.

Padilla, M. et al. (eds), 2007. Love and Globalization: Transformations of Intimacy in the Contemporary World. Nashville, TN: Vanderbilt University Press.

Palmié, S., 2004. "Fascinans or Tremendum? Permutations of the State, the Body, and the Divine in LateTwentieth-Century Havana", New West Indian Guide 78 (3-4): 229-268.

Patico, J., 2009. "For Love, Money, or Normalcy: Meanings of Strategy and Sentiment in the RussianAmerican Matchmaking Industry", Ethnos 74 (3): 307-330.

Piscitelli, A., 2006. "Tansnational Sex Travels: Negotiating Identities in a Brazilian "Tropical Paradise”, in Translocalities/Translocalidades: Feminist Politics of Translation in Latin America. Amherst: University of Massachusetts. Retrieved 24 July 2012 from http://www.pagu.unicamp.br.

Povinelli, E. A., 2006. The Empire of Love: Tower a Theory of Intimacy, Genealogy, and Carnality. Durham \& London: Duke University Press.

Quintana, R. et al., 2005. Efectos y futuro del turismo en la economía cubana. La Habana: Instituto Nacional de Investigaciones Económicas.

Rapport, N. \& J. Overing, 2000. "Stereotypes", in N. Rapport \& J. Overing (eds), Social and Cultural Anthropology: The Key Concepts, 343-349. London \& New York: Routledge. 
Sánchez Taylor, J., 2000. "Tourism and 'Embodied' Commodities: Sex Tourism in the Caribbean”, in S. Clift \& S. Carter (eds), Tourism and Sex: Culture, Commerce and Coercion, 41-53. London \& New York: Pinter.

Schwartz, R., 1999. Pleasure Island: Tourism and Temptation in Cuba. Lincoln \& London: University of Nebraska Press.

Simoni, V., 2008a. “'Riding' Diversity: Cubans'/Jineteros' Uses of 'Nationality-talks' in the Realm of their Informal Encounters with Tourists" in P. Burns \& M. Novelli (eds), Tourism Development: Growth, Myths and Inequalities, 68-84. Wallingford, Cambridge Ma: CAB International.

-, 2008b. "Shifting Powers: The (De)Stabilization of Asymmetries in the Realm of Tourism in Cuba". Tsansta: Review of the Swiss Anthropological Society 13: 89-97.

-, 2009. “Touristic Encounters in Cuba: Informality, Ambiguity, and Emerging Relationships". Unpublished $\mathrm{PhD}$ thesis. Leeds Metropolitan University.

-, 2011. "L'interculturalité comme justification: Sexe 'couleur locale' dans la Cuba touristique", in Anne Lavanchy, Fred Dervin, \& Anahy Gajardo (eds), Anthropologies de l'interculturalité, 197-225. Paris: L'Harmattan.

Simoni, V. \& S. McCabe, 2008. "From Ethnographers to Tourists and Back Again: On Positioning Issues in the Anthropology of Tourism", Civilisations 57 (1-2): 173-189.

Sykes, K., 2009. "Residence: Moral Reasoning in a Common Place - Paradoxes of a Global Age", in K. Sykes (ed.), Ethnographies of Moral Reasoning: Living Paradoxes of a Global Age, 3-40. New York: Palgrave Macmillan.

Time Out: Havana \& the Best of Cuba, 2004. London: Penguin.

Valle, A., 2006. Jineteras. Bogotá: Planeta.

Zelizer, V.A., 2005. The Purchase of Intimacy. Princeton, NJ: Princeton University Press.

Zigon, J., 2010. "Moral and Ethical Assemblages: A Response to Fassin and Stoczkowski”, Anthropological Theory 10 (1-2): 3-15. 
